\title{
THE LOAN SHARK PROBLEM IN THE SOUTHEASTERN STATES
}

\author{
Wiritam Hays Simpson*
}

Because of the increase in problems associated with the business of money lending in the United States many of the states passed regulatory acts. The movement extended to the Southeastern area where all states, including Alabama, Florida, Georgia, Louisiana, Mississippi, Maryland, North Carolina, South Carolina, Tennessee, Virginia, and West Virginia, enacted legislation which established legal interest rates. ${ }^{{ }^{-}}$ These rates varied slightly, with all states now limiting the annual rate to 6 per cent except Georgia and Florida where interest rates were set at 7 and 8 per cent respectively. While 6 per cent per annum is the maximum contract rate in Maryland, North Carolina, Tennessee, Virginia, and West Virginia, the rate in writing is 7 per cent in South Carolina, 8 in Alabama, Georgia, Louisiana, and Mississippi, and ro per cent in Florida.

The civil penalties imposed in actions on usurious contracts of course vary in the different states. Louisiana law contains no provision for civil penalties but in West Virginia, Virginia, Tennessee, and Maryland forfeiture of excess over legal rate may be had through legal action while forfeiture of all interest is provided for in the laws of Alabama, Florida, Georgia, Mississippi, South Carolina, and North Carolina. The laws of the latter state also provide for the forfeiture of double interest paid on loans made on household and kitchen furniture.

No criminal penalties are provided for violation of the usury laws in Alabama, Louisiana, Mississippi, Maryland, Tennessee, Virginia, and West Virginia, but in Florida, Georgia, and North Carolina it is, under various circumstances, a misdemeanor to make usurious charges.

Thus in the various Southeastern states the loan shark might lose his usurious interest, in several states suffer more serious civil consequences, and in a few jurisdictions be subject to criminal penalties. However, these possibilities are largely äcademic for usury is very difficult to prove under the usury statutes. The fact that the necessitous borrowers are willing to promise all that is demanded of them in order to obtain financial relief has resulted in numerous devices to evade the usury

- A.B. 1926, Tusculum College; M.A. 1928, Ph.D. I935, Duke University. Associate Professor of Political Science, Duke University. Author, The Small Lonn Problem in the Carolinas (i941), Lipe in Mill Communities (rg43), Workmen's Compensatjon in South Carolina (1949). Contributor to legal periodicals.

${ }^{2}$ For usury laws, see ALA. Code ANs. tit. 9, \$\$60-67 (1941); FlA. Stat. ANn. \$\$687.01-687.10 (1944); GA. CODE ANN. \$\$57-IOI-57-II7 (1935); LA. CIv. CODE ANN. arts. I935-1940, 2923-2924 (1945); LA Rev. STAT. tit. 9, \$350I (1950); MD. ANN. CODE art. 49, \$5r-6, and art. 8, \$16 (195I); Miss. COde ANN. \$\$36-4I (1942); N. C. Gen. Stat. ANN. \$\$24-1-24-7 (1943); Code of Laws of S. C. \$\$8.2-8.9 (I953); Tenn. Code ANN. \$\$7301-73I6, III31-III32 (Williams 1934); West. VA. Code ANN. $\$ \$ 4627-4632$ (1949). 
laws. These include such subterfuges as brokerage fees, service charges, investigation fees, pretended sales' and attorneys' fees. In addition the loan sharks have prevented their victims from obtaining possession of adverse evidence such as the promissory notes and receipts without which it would be difficult to prove cases. Therefore, for these and other reasons, relatively few victims have instituted legal action against loan sharks and only in a small percentage of the cases have convictions of the money lenders been secured.

\section{The UNIForm SMaLI Loan LAW}

To protect the thousands of borrowers of small sums of money from the high rates of interest charged and from other bad practices of the loan sharks, the Russell Sage Foundation recommended the First Draft of the Uniform Small Loan Law in rgr6. A number of the Southeastern states have experimented with various versions of the Act and today the Uniform Small Loan Law, in one form or another, is the basis for effective control of the loan shark problem in Maryland, West Virginia, Virginia, Florida, and Louisiana. ${ }^{2}$

It would be futile to compare all the provisions of the small loan laws of the five states mentioned above; but certain similarities and differences might well be noted. All of the states provide for the licensing of persons engaging in the business of making loans of $\$ 300$ or less at rates of interest greater than otherwise provided by law. Florida allows the highest rate, $3 \frac{1}{2}$ per cent a month on the unpaid balance on all loans under $\$ 300$. Louisiana and West Virginia permit $3^{1 / 2}$ per cent charges a month on loans up to $\$ 150$ and $2 \frac{1}{2}$ on those between $\$ 150$ and $\$ 300$. The rates in Maryland and Virginia are 3 and $2 \frac{1}{2}$ per cent a month respectively, on the unpaid balance.

Some of the loans executed are mere "signature" loans while others are secured by co-signers, mortgages on automobiles or household furniture, or wage assignments. Wage assignments, as a means of security for loans, have not experienced great popularity for they often place employers in the position of bill collectors in business transactions in which they have not the slightest interest. While Maryland and Florida have outlawed the assignment of wages as security for loans, it is permitted in Virginia and West Virginia, and also in Louisiana if consent of the employer has been obtained either before or any time after the loan is made. The laws of these last three states provide, however, that under the assignment not more than to per cent of the borrower's salary, wages or commissions can be collected from the employer of the borrower by the lender on each pay day of the borrower.

Provisions for licensing lenders are included in the laws of all of the above mentioned states. The licensing and examining is done by the Department of Banking in three of the states, while these duties are entrusted to the Administrator of Loan Laws in Maryland and the Controller in Florida.

\footnotetext{
${ }^{2}$ For small loan acts, see FLA. STAT. $\$ \$ 5$ I6.0r to 5 r6.26 (I949); LA. REv. STAT. tit. 6, $\$ 571-593$ (1950); MD. CODE ANn. art. 58A, $\$ \$ 1-23$ (I95I); VA. Code ANn. $\$ \$ 6-294$ to 6-338 (I950); W. VA. CODE ANN. $\$ \$ 4653(1)-4653(26)$.
} 
The small loan laws of the five states contain similar provisions to protect the borrowers. They require, among other things, that every licensee give the borrower, when the loan is made, a clear statement of the essential facts; give the borrower itemized receipts for all payments; permit him to make repayments at any time, in any amount; display a schedule of charges; and upon complete payment, cancel, release, and return all obligations and securities signed by the borrower.

\section{States With INoperative Laws}

Four of the Southeastern states-Alabama, Georgia, Mississippi, and Tennesseehave largely inoperative small loan laws and are therefore troubled with loan sharks. While this business is, of course, illegal under the usury laws of all of the states of the area, the penalties for usury are, as has been pointed out, generally civil and mild. Since proof of usury charges is difficult to obtain and legal services expensive, if not prohibitive, for small cases, few borrowers of small sums of money seek redress in the courts. However anti-loan shark drives have been sponsored from time to time by Better Business Bureaus, Junior Chambers of Commerce, Bar Associations, or other groups in many of the states. The results of such drives might well be noted in two of the four states which have ineffective small loan laws.

\section{Alabama}

Legislation enacted in 1927 had some of the features of the Uniform Small Loan Law, but applied only to Jefferson County in which Birmingham is located. However the 1945 act as revised in $195 \mathrm{r}$ has state wide application. ${ }^{3}$ The law applies to loans of not over $\$ 300$ and requires that lenders be licensed and supervised by the bureau of loans. The maturity of the loans is limited to thirty-six months, and false advertising of, and the taking of real estate as security for, loans is prohibited. An unusual feature is the exemption of loans to farmers and loans from landlords to tenant farmers. All loans are limited to 8 per cent a year and since this is not a commercially profitable rate for small loans the law is inoperative. Alabama, therefore, is a fruitful field for loan sharks who shift in ever increasing numbers to the ineffectively regulated areas from those states which have adopted the Uniform Small Loan Law.

Since no money lenders can specialize in making loans of from $\$ 5$ to $\$ 300$ at 8 per cent per annum interest and realize a profit on their business, the lenders in Alabama resorted to various subterfuges which resulted in interest charges of over 200 per cent a year.

Information concerning the serious plight of the borrowers of small sums of money in Alabama was uncovered by the Community Anti-Loan Shark Committee which was composed of the Junior Chamber of Commerce of Birmingham, a committee of the Birmingham Bar Association, and committees from the Congress of Industrial Organizations and the American Federation of Labor. This committee referred all victims of loan sharks to various lawyers who had volunteered their services for free legal aid in such cases.

${ }^{3}$ Ala. Code Anv. tit. 5, $\$ \$ 263-275$ (195I Cum. Supp.). 
Data on some 245 of these cases, as recorded in the anti-loan shark drive of x941942, was tabulated by Lawrence Dumas. This study shows that the illegal lenders in Alabama specialized in relatively small loans, the average principal amount being $\$ 15.65$. The average borrower was indebted to 2.4 loan sharks for a total average principal indebtedness of $\$ 37.5^{2.4}$

The loans were made for a short period of time, practically none for over thirty days. Usually the loans were payable within a week or two weeks and since many of the borrowers were in debt to several lenders they could pay only the usurious interest and request that their notes be renewed. This was done frequently, for out of the 203 giving information, the average had been involved with loan sharks for one year, 8.8 months. One had been involved for nine, one for eight, and two for seven years. ${ }^{5}$

Some loan sharks obtain wage assignments or chattel mortgages on household furniture or automobiles while others lend on unsecured notes. Practically all of the loans in this study were unsecured. ${ }^{6}$

Loan sharks usually made loans for short periods of time, generally payable in a week or two weeks, or a month. They generally encourage renewals and make it difficult for borrowers to repay the principal. Of this type were 564 of the 580 loans investigated in Alabama in I94I-I942.

The remaining 16 of the 580 loans were payable in weekly installments over a ten or twelve week period. This small number of installment loans is doubtless due to the reluctance of the lender to use a method of repayment which would more easily permit the borrowers to retire their indebtedness.

The larger the loan, the smaller were the interest charges; but all were far above the 8 per cent per annum allowable under Alabama law. The averages based on size of loans may be noted in the following table. ${ }^{\text {T }}$

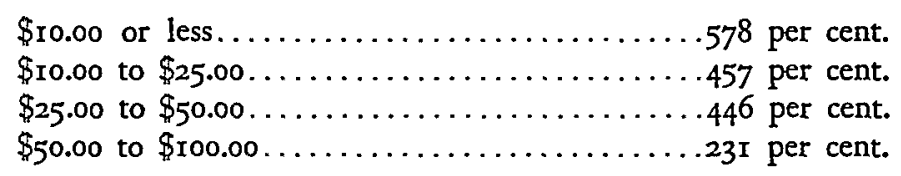

\section{Georgia}

An act similar to the Second Draft of the Uniform Small Loan Act was enacted in Georgia in 1920. It established a maximum rate of $3 \frac{1}{2}$ per cent per month on loans of $\$ 300$ or less but in 1935 an amendment was approved which reduced the maximum rate to $1 / 2$ per cent per month thereby making the law inoperative. ${ }^{8}$ Reputable lenders, being unable to make a fair return in the small loan business at the reduced rate, closed their offices and left Georgia. They were succeeded by the loan sharks.

Various movements to rid the state of loan sharks were promoted and convictions

\footnotetext{
'Two Anti-Loan Shark Drives 33 ff.

${ }^{0} I d$, at $2 \mathrm{I}$.

"Id. at 20.

TId. at 22 .

${ }^{8}$ For copy of law see GA. CODE ANN. $\$ \$ 25-301$ to $25-319,25-9902$ (1935).
} 
of numerous lenders were obtained for violation of the usury laws. In Georgia it had been a misdemeanor since 1908 to "reserve, charge or take for any loan or advance of money, or forbearance to enforce the collection of any sum of money, any rate of interest greater than five per centum per month, either directly or indirectly by way of commssion for advances, discount, exchange, the purchase of salary or wages, by notarial or other fees, or by any contract, contrivance or device whatever. ...."

Lenders not licensed by the Superintendent of Banks who lend $\$ 300$ or less are not permitted to "directly or indirectly charge, contract or receive any interest or consideration greater than eight per centum per annum."10 Lenders licensed by the Superintendent of Banks who make loans of $\$ 300$ or less are allowed to "charge, contract for and receive thereon interest at a rate not to exceed one and one half per centum per month."11 Violation of the above prohibitions is a misdemeanor punishable "by a fine of not more than $\$ 500$, or by imprisonment of not more than six months, or by both such fine and imprisonment in the discretion of the court."12

The civil penalty for charging usurious rates of interest is "to forfeit the entire interest so charged or taken, or contracted to be reserved, charged or taken."13 The Small Loan Law of 1920 includes various restrictions and provides, "If any interest or charges in excess of those permitted by this chapter shall be charged or contracted for or received, the contract of loan shall be null and void and the licensee shall have no right to collect or receive any principal, interest or charges whatsoever."14

Under the above provisions the Solicitor of the Atlanta Judicial Circuit and the Committee on the Enforcement of Usury Laws, which was appointed in 1940 by the Atlanta Bar Association, were able to obtain convictions of various loan sharks in the local courts. Fifteen hundred victims reported to this Committee that they had borrowed more than \$120,000 from "salary buyers." The average amount borrowed on each transaction was $\$ 2 \mathrm{I} .4 \mathrm{I}$ and the average annual interest rate paid was 280 per cent, the customary rate being Io per cent every two weeks. On loans of $\$ 15$ or less the usual rate was 15 per cent every two weeks, or an average annual rate of about 360 per cent. ${ }^{15}$

The information collected by the Bar Association led to the indictment by the grand jury of 33 concerns and 48 individuals; 28 of the 33 companies pleaded guilty. The corporations were fined and where individuals were involved, fines and sentences of twelve months were imposed, with the sentences being suspended during good behavior. ${ }^{16}$ Many of the concerns ceased operations in the area.

Many claims of borrowers of small sums of money were settled without court action and in all cases brought in Atlanta where sentences were suspended on good behavior, restoration of usurious interest was required. Many contracts, involving in all thousands of dollars, were cancelled.

\footnotetext{
D.GA. CODE ANN. tit. 57, \$\$57-I17, 57-9901 (1935).

${ }^{10}$ Id. $\$ 25-317$. ${ }_{12}$ Id. $\$ 25-3 \times 3$.

${ }^{13}$ Id. \$57-112. 11 Id. \$25-113.

is Victor K. MEADOR, LoAN Sharks in GeORGia 25 (1949). ${ }^{20}$ ld. at 33.

${ }^{12} 1 d$. $\$ 25-9902$.
${ }^{20} 1 d$. at 33 .
} 
Recommendations were made to the Georgia legislature to correct the loan shark evil but legislative action was not taken. The dozen small loan companies that remained in operation in Atlanta reduced their excessive charges but complained that they could not stay in business at the reduced rate of interest. ${ }^{17}$

However, after World War II, the high rate lenders began to reappear in Atlanta as the old establishments raised their rates and other loan sharks entered the business. Consequently, because of the many complaints about high-rate money lenders, Paul Webb, Solicitor General of the Atlanta Judicial Circuit, announced, on October I, 1947, that he was taking action against violators of the usury laws.

The investigations which followed revealed that usurious interest as high as I300 per cent per year had been charged.18 A grand jury indicted 23 individuals involving 22 firms. Of this number at least 15 convictions were obtained, the guilty parties being given suspended sentences upon payment of fines ranging from $\$ 500$ to $\$ \mathrm{r}, 000$. First offenders were fined $\$ 500$ and second offenders $\$ \mathrm{r}, 000$. Their sentences were tempered because each of those convicted agreed to discontinue his business. 10

The activity against the loan sharks was temporary and when the prosecutions subsided high rate offices appeared again in both Georgia and Alabama.

\section{States With No Small Loan Laws}

South Carolina is the only state in the Southeast that has no small loan law but it is thought by some observers that North Carolina, for all practical purposes, might also be included in this category.

In South Carolina the interest rate is established by law at 6 per cent, or 7 per cent in written contracts. ${ }^{20}$ A $I^{1 / 2}$ per cent monthly "premium" is limited to industrial banks which "make personal loans on the monthly payment plan and which require no security except endorsements, and which are incorporated in South Carolina, and which do not receive deposits...."

The subject of interest rates is also dealt with in Section 8-233 of the Code of Laws of South Carolina which provides as follows:

Banks, banking institutions and other lending agencies doing business in this State may make loans and advances of credit to persons in amounts of not less than ten dollars and not more than one thousand dollars, payable in installments, for the financing of purchases and for other desirable purposes, over a period of not less than six months and on all such loans are allowed to make interest or discount charges at the rate of not exceeding seven per cent per annum just as if the entire amount of the debt matured on the date the last instalment becomes due. For example, if the amount of the debt is one hundred dollars, payable in installments as aforesaid maturing over a period of twelve months, and the rate seven per cent per annum, the amount of such interest or discount shall be seven dollars.

\footnotetext{
${ }^{17} I d$. at 35 .

${ }^{18}$ Thrower, Allanta Loan Shark Drive Continues, Quarterly Report, published by Conference on Personal Finance Law, Winter, 1947, p. II.

${ }^{20}$ MEAdor, op. cit. supre note 15 , at $36 . \quad{ }^{20}$ Code of LAwS of S. C. $\$ 8.3$ (1952).
} 
A minimum charge of one dollar may be made on loans in lieu of interest..$^{21}$ This provision has made possible the lending of small sums of money for a short period of time by loan companies under a dollar discount plan. Under this plan, for example, a person who borrows \$ro signs a note for $\$ 1 x$ and at the end of a week pays back the latter amount. He therefore pays $\$ 1$ for the use of $\$ 10$ for one week or a rate of 520 per cent interest per annum on the loan.

Borrowers of small sums of money in South Carolina often pay fees, such as brokerage, investigation or booking fees, in addition to the legal interest charges stated in the promissory notes signed by them. They are likewise subjected to the numerous subterfuges used by lenders to evade the usury laws in other states.

In 1938 and 1939 the writer interviewed ro42 borrowers of small sums of money in $\mathrm{I}_{4}$ cities and towns of South Carolina. The average interest rate in the various cities on loans of $\$$ io or less ranged from 278 to 598 per cent per year for white borrowers and 322 to 955 per cent for Negro borrowers. For loans of $\$ 10.01$ to $\$ 25$ the average rate varied between 212 and 362 per cent for white and from 183 to 353 per cent per annum for colored borrowers. ${ }^{22}$

The writer revisited several of the 'cities in South Carolina in June, 1953, and found that while the number of small loan offices had increased in the state, the interest charges were about the same as reported in 1938 and $x 939$. In the interviews with borrowers of small sums of money in Columbia, Greenville, and Spartanburg each person was asked the amount of money actually received, the amount of each payment, and the number of payments required to retire the loan. On loans of from \$10 to $\$ 50$ inclusive, the borrowers interviewed in Columbia paid from 189 to 576 per cent interest per annum; in Greenville from 240 to 433 per cent; and in Spartanburg the rate of interest charged was from 240 to 693 per cent per annum.

\section{North Carolina}

In North Carolina the legal rate of interest is limited to 6 per cent per annum ${ }^{23}$ and as in South Carolina the loan sharks enjoy a thriving business. It was found from interviewing $118 \mathrm{I}$ borrowers in $194^{\circ}$ that the average annual interest rate on loans of \$ro and less varied from 335 to 522 per cent and on loans between \$ro.or and $\$ 25$ the rate ranged from 279 to 444 per cent in 7 different cities in North Carolina. ${ }^{24}$

An effort to place the small loan companies under the supervision of the Commissioner of Banks was defeated in the I94I session of the General Assembly while a proposal which would enable banks more actively to enter the small loan field received unfavorable action in 1943 .

In 1945 the columns of various newspapers of the state carried descriptions of a large operation of a "Ponzi" character in which money was borrowed at a guaranteed rate of 5 per cent a week and loaned at a higher rate. The promised 5 per cent

${ }^{21} I d . \$ 8.4$

22 W. H. Simpson, The Small Lonn Problex of the Carolisas 25 (1941).

${ }^{23}$ N. C.; Gen. Stat. \$24-I (I944).

${ }^{24}$ Simpson, op. cit. supra note 22 , at 24 . 
return per week attracted a multitude of investors not only in North Carolina but also from distant places such as Massachusetts, Florida, Canada, and Alaska. Borrowers applied for loans at io per cent a week, or at the rate of 520 per cent per annum. 25

Critical newspaper comments plus real or threatened investigations of the money lending business led to a run on the enterprise. In August, 1944, bills of indictment were drawn and the operator was indicted by the grand jury of Craven County.

In the much publicized trial which followed prosecution could not be had under the law for the usurious nature of the business so the prosecution and conviction was based upon "obtaining money by fraud." The loan broker was sentenced to prison. ${ }^{26}$

In 1945 the General Assembly of North Carolina in seeking a solution to the loan shark problem enacted a law which placed the loan agencies under the supervision of the Commissioner of Banks ${ }^{27}$ and provided that a fee of $\$ 2.5^{\circ}$ could be charged in addition to 6 per cent interest per annum on installment loans of $\$ 50$ or less. ${ }^{28}$

The Banking Commission was authorized to make rules and regulations governing loan agencies or brokers which might "be necessary or desirable in providing for the protection of the public and the efficient management of the loan agencies or brokers."29

Pursuant to this authorization the State Banking Commission issued an order, effective June $\mathrm{I}$, I945, which provided for examination of loan agencies, prescribed the keeping of certain records by the loan companies, required the making of regular reports by the loan companies to the State Banking Commission, and prohibited the dividing of loans and the charging of excessive fees. ${ }^{30}$

The new regulations had hardly gone into effect before it became obvious that the control was inadequate to care for the small loan problem in the state. Loan agencies began to require that life insurance be purchased on each loan, later accident and health insurance was added, and more recently some agencies require borrowers also to purchase mortgage non filing insurance.

In a statement prepared by the Commissioner of Banks, Gurney P. Hood, in I95I, for the General Assembly of North Carolina on accident and health insurance premiums on policies issued as security to loans made by small loan companies, certain startling disclosures were made. The report included an analysis for the year $195^{\circ}$ of the business done by 9 small loan companies operating 20 offices in North Carolina. The average total loans of the 9 companies amounted to $\$ 1,308$,I94.I8. The companies collected and remitted to an out-of-state insurance company accident and health premiums on policies securing these loans an amount of not less than $\$ 955,735.94$.

\footnotetext{
${ }^{25}$ Durham Herald Sun, Feb. 4, 1945, \$2, p. 3.

${ }^{20}$ State v. Devenport, 227 N. C. 475,42 S. E. $2 d 686$ (I947).

${ }^{27}$ N. C. Gen. Stat. $\$ 53^{-164}$ (1950).

${ }^{28} I d . \$ \$ 53-\mathrm{I} 66,53-\mathrm{I} 4 \mathrm{I}$. ${ }^{20} I d . \$ 53-\mathrm{I} 65$.

${ }^{30}$ Banking laws of North Carolina, Order No. 4 irj-tis.
} 
In another analysis of 50 small loan companies operating 54 offices in North Carolina, Mr. Hood reported that in $195^{\circ}$ the average total loans of all $5^{\circ}$ of the companies amounted to $\$ 1,255,919.72$. These companies that year collected and remitted accident and health insurance premiums in an estimated amount of not less than $\$ 879,143.84$.

One small loan company showed an unpaid balance on loans of $\$ 17,586.49$ as of December 3r, I950. Accident and health premiums collected from borrowers during the quarter ending December 3I, I950 amounted to $\$ 3,792.4 \mathrm{I}$. The manager of the company as an insurance representative received commissions totaling \$2,973.23. Mr. Hood pointed out that since this report only covered a period of three months it was possible that over a twelve month period the borrowers from this company would pay premiums of $\$ 15,169.64$ on net loans of $\$ 17,586.49$ and that the agent's commission would be approximately $\$$ II,892.92.

Mr. Hood also pointed out in his statement to the 195I General Assembly that a small loan company operating in Raleigh, North Carolina collected insurance premiums of $\$ 14,316.72$ in $195^{\circ}$ on average loans of $\$ 21,434.20$ while another company in the same city collected premiums of $\$ 50,746.18$ on average loans of $\$ 73,988.28$. A tabulation of reports made by 73 companies operating 107 offices in North Carolina showed net loans of $\$ 3,218,535.20$ on which Mr. Hood estimated the total insurance premiums amounted to approximately $\$ 2,339,382.30$. The commissions on the sale of this insurance received by the loan companies amounted to $\$ 1,169,691 . x_{5}$.

To illustrate the effect of these practices on the borrowers Mr. Hood mentioned several cases. One, an attendant at a state hospital whose salary was $\$ 66.80$ a month, borrowed $\$ 32.28$ on January 4, 1949. During the following two years he borrowed the same amount six different times and still owed $\$ 32.28$. The accident and health insurance during that period amounted to $\$ 26.23$. A household servant whose salary was $\$$ i2.00 a week borrowed $\$ 32.48$ on April II, I949 and during the following twenty-one months made six additional loans for the same amount and still owed $\$ 32.48$. The insurance premiums on these seven loans amounted to $\$ 30.59$. A janitor whose weekly wage was $\$ 22$ borrowed $\$ 26.40$ on October I7, I949. During the following fifteen months the loan was renewed thirteen times and the insurance premiums amounted to $\$ 49$. The borrower still owed $\$ 26.88$.

Mr. Hood referred to the above practices as a legalized accident and health insurance racket and suggested that the Commissioner of Insurance be given the authority to regulate the rates on this type of insurance. ${ }^{31}$ The General Assembly in acting favorably upon this request passed an act authorizing the Commissioner of Insurance to disapprove the issuance of any policy of accident and health insurance if he found benefits unreasonable in relation to the premium charged or if the policy contained unjust, unfair, inequitable, misleading or deceptive provisions. ${ }^{32}$

After a series of public hearings a set of regulations was issued by the Commis-

s1 The data on insurance and loans were taken from three statements prepared by Commissioncr of Banks, Gurney P. Hood, for the members of the r95I General Assembly.

${ }^{32}$ N. C. Gen. Stat. $\$ 58-254$ (1950). 
sioner of Insurance in July I950 and became effective September I, I950. They were later revised, and the nine regulations were made effective September $\mathrm{r}$, I95I.

These regulations, in attempting to correct certain bad practices, require a complete disclosure to the borrower of the kind, amount of coverage, and the cost of insurance sold to him. The insurance company is required to mail the borrower within the thirty days after execution of the contract a copy of it clearly setting forth the amount of the premium, terms, limitations, exceptions, and the like. The borrower must be given the option of furnishing insurance in any duly licensed company of his choice.

Policies must be written for the full term for which the premium is charged. Loan companies are forbidden to accept a life insurance policy as protection on a loan from any borrower where the benefits exceed the amount of the loan, nor may the life insurance contract exceed the term of the loan contract.

Loan agencies are forbidden to write accident, health, disability or hospital insurance in which the monthly benefits exceed the amount of the loan, or in any event in excess of \$roo. Where collision coverage on automobiles is furnished, no hospital, accident, disability or health insurance may be written with loans where the monthly benefits exceed the amount of monthly payment on the loan.

Where a single interest policy is written in connection with a loan the borrower must be informed that his own interest is not protected. The borrower must be informed of any cancellation and the pro rata unearned premium returned to him. When the loan is repaid' in advance, the borrower must be repaid the pro rata unearned premium. A policy writing fee of not over thirty-five cents may be charged when a policy is issued.

Willful violation of any of these regulations is cause for the revocation of the agent's or insurance company's license by the Commissioner of Insurance. ${ }^{33}$

According to the report of the State Banking Commissioner there were 155 small loan offices operating in North Carolina on December 3r, 1951. These offices enjoyed a total income for I951 of $\$ 3,287,292.34$ from the following sources: Interest, $\$ 76 \mathrm{r}, 274.90$; fee, loans, $\$ 950,591$.46; insurance commissions, $\$ 1,433,254.96$; other charges, loans $\$ 6 \mathrm{r}, 821.89$; other earnings $\$ 80,349.13$. The report showed that the income from interest and from loan fees amounted respectively to 23.16 and 28.92 per cent while the income from insurance commissions was 43.60 per cent of the total income. ${ }^{34}$

To the persons wishing to borrow money the insurance feature of the loans is of no special interest as in most cases it is the lender that is seeking the so-called "protection." It represents an extra cost to the borrower and additional income to the lender. Therefore, it is almost impossible to obtain a loan at the vast majority of the agencies without buying insurance. ${ }^{35}$

\footnotetext{
${ }^{33}$ For a complete text of regulations, see Insurance Regulations, effective September I, I95I, issued by Waldo C. Cheek, Commissioner of North Carolina Insurance Department.

36 Reports on the Condition of State Banks at the Close of Business on December 31, i95i, State of North Carolina Banking Department 78 (1952).

${ }^{35}$ See article by Barton Hickman, You Can Borrow Easily But It Costs . . and How, Greensboro Daily News, June 7, 1953, p. I.
} 
The loan plans of the various small loan companies differ in some details but generally speaking they are very similar. A $\$$ io loan may ordinarily be obtained for an eight week period at numerous loan companies by signing a note for $\$ 14.64$ to be paid back in eight installments of $\$ 1.83$ a week. The difference between the \$ro received by the borrower and the note for $\$ 14.64$ is accounted for by the fee of $\$ 2.50$ and fourteen cents interest allowed by law plus five cents for life insurance, \$I.Io for accident and health insurance, thirty-five cents premium writing fee, and a notary fee of fifty cents. If these charges were considered as compensation paid for the use of money the interest rate on the \$1o loan would be $53^{6}$ per cent per annum.

The terms for a $\$ 25$ loan for a twelve week period are a little better. In such instances a note is signed for $\$ 33.60$ which includes the following charges; $\$ 2.50$ fee; forty-five cents interest; seventeen cents for life insurance; $\$ 4.13$ for accident and health insurance; thirty-five cents premium writing fee; and $\$ 1$ notary fee. Such loans are usually paid back in twelve installments of $\$ 2.80$ a week. In such transactions the annual interest rate is 275 per cent when all charges are considered as a part of the cost of the loan.

Various companies do not assess notary fees and at least one company in North Carolina does not sell insurance policies on \$1o loans. Where the most favorable terms are available, that is the $\$ 2.5^{\circ}$ fee plus 6 per cent interest as allowed by law, the borrower is paying an annual rate of 303 per cent on \$ro loans paid back in eight weekly installments.

Various possible solutions to the small loan problem have been suggested by public spirited residents of the state but to date no satisfactory plan has been put into operation. Recently the Commissioner of Banks of North Carolina had the following to say on the subject: ${ }^{36}$

There is little this department can do about the practices of small loan companies. We have no supervision over them except in checking the interest and fees on their loans. Even where excessive interest has been charged, there is nothing the banking commissioner can do about it. Under the state law the action has to be brought by the injured party, not the State Banking Department. All we could do, say in proven wholesale violations of the law, would be to revoke their banking permit. Actually the small loan companies ought to come under the supervision of the State Insurance Department. These companies are not in the banking business. They're in the insurance business. More than three-fourths of their income is from the insurance they sell.

The Commissioner of Insurance, Waldo Cheek, has pointed out that additional abuses have grown up in the selling of insurance policies by the small loan companies. Investigators on his staff have found companies that collect money for insurance and never write the policies. Many other violations of the insurance regulations doubtless go undetected; there are only four investigators on his staff and they have many duties to perform in addition to checking insurance operations of the small loan companies of North Carolina. ${ }^{37}$

${ }^{30} I d$. at 5 .

${ }^{37}$ Ibid. 
Insurance of Small Loans in Selected Southeastern States

There is a division of opinion whether an insurance premium is an additional charge for the use of money and is therefore prohibited under any, small loan statute that prohibits charges other than authorized ones. The Georgia Court of Appeals, on February 20, 1953 held that where the cost of insurance charged by a lender to a borrower actually represents a device for the reservation of interest, then the amount of such charge is to be considered in determining whether the lender has violated the usury law. ${ }^{38}$

Several of the Southeastern states have, by regulations or amendments to the small loan law, extended insurance protection in connection with small loans.

The regulations of the Comptroller in Florida permit licensed agents to write credit life insurance on small loan borrowers. An explanatory letter by the Chief of the Small Loan Department of Florida, dated August 27, 1952 advised small loan licensees as follows: ${ }^{39}$

Credit life insurance may be written on smail loan borrowers on either the decreasing term or level term basis, by an agent licensed by the Insurance Commissioner of Florida. A small loan licensee is prohibited from accepting any sum of money, profit or advantage from the sale of life insurance.... Such insurance must not exceed the original amount of the loan nor the term of the loans.

The Small Loan Law was amended in Louisiana so that reasonable credit life insurance could be sold to a borrower in a licensee's office up to the amount of the loan or not exceeding the reasonable value of the property securing the loan on condition that "a reasonable and bona fide relation to the existing hazard or risk of loss" is observed. The law states that any gain or advantage to the licensee "from such insurance or its sale shall not be deemed to be additional or further interest, discount or charge in connection with such loan." ${ }^{\text {"0 }}$

In a directive by the State Banking Commission of Louisiana, dated April 7 , 1953, certain procedures were outlined to be followed in the sale of insurance on loans and it was also stated that " $\%$ reducing level term insurance for the principal amount of the loan is reasonable." It directed that "where the interest rate is capitalized and added to the note only the principal can be insured."

The Small Loan Law in Maryland authorizes and regulates the sale of credit life insurance. The licensee is prohibited from accepting a commission. ${ }^{41}$ About 60 per cent of the accounts are covered by life insurance on a declining balance plan, $\$ 1$ per hundred. About I per cent of the loans are covered by automobile insurance. $^{42}$

As authorized by the Small Loan Act ${ }^{43}$ the Commissioner of Banks of West Vir-

${ }^{38}$ Peebles v. State, 87 Ga. App. 649 , 75 S. E. $2 d 35$ (1953).

${ }^{30}$ The American Banker, July 14, 1953 , p. 7 .

${ }^{\circ}$ LA. Rev. Stat. tit. 6, $\$ 589$, amended by Act $\times 69$, Acts of State of Louisiana, 1952, p. 402.

${ }^{11} \mathrm{MD}$. CODE ANN. art. 58A, \$18 (Flack, 195I).

${ }^{4}$ Letter from Deputy Administrator of Loan Laws of Maryland, John W. Dallam, to William Hays Simpson, July 14, 1953.

${ }^{43}$ W. VA. CODE ANN. $\$ \$ 4653$ (12) (1949). 
ginia, John H. Hoffman, on August II, I952, gave written permission to the small loan companies to write in their offices diminishing term life insurance at a rate not to exceed $\$ \mathrm{I}$ per hundred. The instructions provided that the borrowers could not be required to purchase insurance in connection with loans; set \$roo as a minimum amount of any loan to be insured; and limited the amount of the insurance to not more than the size of the loan and the term of the insurance policy to not longer than the term of the loan. On loans made to husband and wife and on loans made on notes which have both a maker and co-maker only the wage earner and the maker respectively could be insured. When insured borrowers repay their loans before they are due all refunds of premiums of fifty cents or more must be made.

\section{Summary and Conclusions}

In the preceding pages the usury laws of the Southeastern states were briefly summarized and note was made of the type of regulatory small loan legislation in force in the various jurisdictions. Five states-Virginia, West Virginia, Louisiana, Maryland, and Florida-enjoy effective control under laws similar to the Uniform Small Loan Law. The states of Tennessee, Alabama, Georgia, and Mississippi have inoperative laws, while South Carolina and, for many practical purposes, North Carolina have no small loan laws.

In a review of the small loan problem in Alabama, Georgia, North and South Carolina various bad practices of the high rate lenders of those states were mentioned. Not the least of these is the sale of various forms of insurance by the loan agencies. While insurance gives the borrowers certain minor benefits, the purchase of it increases the cost of credit to the borrowers and the profits to the lenders. The report of the State Banking Commissioner of North Carolina shows that over 43 per cent of the income of the small loan companies of the state in 1951 came from commissions on the sale of insurance.

To solve the problems arising from the sale of insurance policies by loan agencies the states of West Virginia, Florida, Maryland, and Louisiana have either amended their small loan laws or have issued directives to adequately care for the problem.

There has been general agreement in some jurisdictions that if the lenders wish the additional protection of life insurance on the borrowers to protect their loans the sale of such should be permitted but at no profit to the loan agency. If this limitation were adopted in North Carolina, much less insurance would be sold by the small loan agencies and the cost of loans to thousands of borrowers would be reduced.

To care adequately for the small loan problem in this area more states will have to join the five Southeastern states which have already approved laws similar to the Uniform Small Loan Law. A uniform rate of interest of from $2 \frac{1}{2}$ to $3 \frac{1}{2}$ per cent per month on the unpaid balance, which has been found adequate in those states enjoying effective regulation of the small loan business, should be established as an all-inclusive rate and no other charges should be permitted against the borrower of small sums of money. 